\title{
Does Tourism Impact Aquatic Insects in a High Altitude Stream?
}

\author{
Carlos Antonio Bispo ${ }^{1}$, Anete Pedro Lourenço ${ }^{1}$ \& André Rinaldo Senna Garraffoni²
}

1. Universidade Federal dos Vales do Jequitinhonha e Mucuri, e-mail: carlosbispotracks@yahoo.com.br, anete.lourenco@ufvjm.edu.br.

2. Universidade Estadual de Campinas, e-mail: arsg@unicamp.br (Autor para correspondência ${ }^{\varpi}$ ).

\section{EntomoBrasilis 8 (2): 96-104 (2015)}

\begin{abstract}
Human activity often has a negative effect on stream quality and the biodiversity of aquatic fauna. The present study investigated the distribution patterns of aquatic insect populations in the Sentinela stream in Biribiri State Park, Diamantina, Minas Gerais, Brazil, and we correlated the patterns to possible impacts caused by tourists. We sampled the aquatic insect population few days before and few days after the holidays and monthly during the year. Fifteen groups of samples were taken from January through December 2011 at four different sites. For each site, three subsamples were taken by drifting the entomological net and disturbing the substrate using the kick method. 3601 individuals were collected, and 8 orders and 41 families were identified. Environmental indices showed excellent water quality for sites 1 and 2, which are minimally affected by tourism and average water quality for sites 3 and 4, which are highly impacted by tourism. Three of the four holiday periods analyzed showed a significant decrease in insect abundance after the holiday. The richness and diversity of the aquatic insect fauna did not show seasonal fluctuations, despite differences in stream flow velocity during the dry and rainy periods. Our results indicated that the disturbances caused by tourism affect directly the diversity and abundance of aquatic insects in the Sentinela stream. In addition, these insects were suitable for the evaluation of human impacts caused by tourism in the conservation of freshwater ecosystem.
\end{abstract}

Keywords: Biodiversity; Brazil; Freshwater; Tourism impact.

\section{O Turismo Impacta os Insetos Aquáticos em um Riacho de Alta Altitude?}

Resumo. A atividade humana tem afetado negativamente a qualidade dos ambientes lóticos e a biodiversidade da fauna aquática. O presente estudo investigou os padrões de distribuição das populações de insetos aquáticos no córrego Sentinela no Parque Estadual do Biribiri, Diamantina, Minas Gerais, Brasil, e correlacionou esses padrões com possíveis impactos causados pelas atividades do turismo. As populações de insetos aquáticos foram amostradas alguns dias antes e alguns dias após dos feriados e mensalmente durante o ano, totalizando quinze amostras entre os meses de janeiro e dezembro de 2011 em quatro locais diferentes. Para cada local, foram realizadas três sub-amostras com a ajuda de rede entomológica e o substrato foi revolvido com os pés. Foram coletados 3601 indivíduos, os quais foram identificados 8 ordens e 41 famílias. Por meio dos índices ambientais foi possível observar que os pontos 1 e 2 possuem excelente qualidade da água e são minimamente afetados pelo turismo, por outro lado os pontos 3 e 4 possuem uma qualidade de água intermediária e são altamente impactados pelo turismo. Três dos quatro feriados estudados mostraram uma diminuição significativa na abundância de insetos após o feriado. A riqueza e a diversidade da fauna de insetos aquáticos não mostraram flutuações sazonais, apesar da ocorrência de diferentes velocidades de vazão durante os períodos seco e chuvoso. Nossos resultados indicaram que os distúrbios causados pelo turismo afetam diretamente na diversidade e abundância dos insetos aquáticos no córrego Sentinela. Além disso, esses insetos se mostraram adequados para a avaliação de impactos antropogênicos causados pelo turismo na conservação de ecossistemas lóticos.

Palavras-chave: Água doce; Biodiversidade; Brasil; Impacto do turismo.

TT The use of biological parameters to measure water quality is based on the responses of organisms in relation to their environment. As water bodies are subject to numerous disturbances, the aquatic biota responds and has different tolerances to natural or anthropogenic impacts (BARBOUR et al. 1999). Efforts to protect aquatic ecosystems depend on the ability to distinguish between the effects of human alteration and natural variation, making it desirable to categorize the influence of human alteration on biological systems (CAirns-JR. \& PratT 1993).

Environmental assessments or continuous stream monitoring contribute to early identification of impacts that can cause serious and irreversible damage to aquatic ecosystems. However, it is essential that the tools used in these assessments or monitoring are sufficiently sensitive to detect small changes in the natural conditions of the stream. If these tools are only able to detect heavy impacts or degradation in advanced stages, they will be ineffective for to measure water quality or environment health (RodRIGUes et al. 2008).
A valuable tool for evaluating the responses of this biological system to changes in environmental conditions is the use of bioindicators, such as aquatic insects (GoularT \& CALLISTO 2003). Several researchers (e.g., CALListo et al. 2001; McGeoch 2007; TupinAMBÁs et al. 2014) have demonstrated the advantages of this group of animals as a biological tool to measure environmental health because they have several useful features for this purpose: 1 - they are sedentary; 2 - they are collected in most aquatic environments; 3 - they have short life cycles, which enable them to more quickly reflect the environmental changes through alterations in their population structures; 4 - they feed in, on or around the sediment, where toxins tend to accumulate; 5 - they have great biological diversity, which implies a wide range of responses to different environmental impacts; 6 they are ubiquitous and can respond to disturbances in aquatic environments at any time of the year; 7 - they are collected using simple and low-cost sampling methods that do not damage the

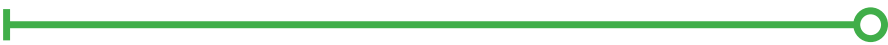

Financial support: Fundação de Amparo a Pesquisa de Minas Gerais (FAPEMIG). 
T aquatic environment.

Currently, more people are visiting protected areas (e.g., national and state parks) to experience nature, adventure tourism, and recreation (BUCKLEY 2003). However, tourists can have impacts and cause environmental degradation if the tourism is not appropriately managed (CHOIA \& SirAKAYA 2006; Monz et al. 2013). Human impacts can reduce the number and diversity of taxa in aquatic insect communities (KerAns \& KARR 1994; DinAKARAN \& AnBalagan 2007; Monz et al. 2013). Following BuCKLEy (2003), the detection of tourism impacts over a given time period in a given protected area requires (1) a sampling pattern with non-impacted control sites as well as sites with impacts and (2) measurements before, during and after the time period of concern. Thus, the present study aimed to examine the temporal variations in the aquatic insect community structure of the Sentinela stream to relate them to possible impacts of tourism in Biribiri State Park (PEBI), before and after holidays (immediate changes) and during the course of the year.

\section{MATERIALS AND METHODS}

Study Area. The study was conducted in Biribiri State Park in the Municipality of Diamantina, Minas Gerais State, Brazil. The surroundings of the park are subject to intense anthropogenic pressures such as tourism, riparian deforestation, and permanent residents within and close to the park, which have impacted several areas. The aquatic environment selected for this study was a low order stream called Sentinela stream. The stream channel tends to be narrow and moderately sinuous, with a rocky bottom alternating with stretches of sandy bed. The Sentinela stream enters the main channel of the Ribeirão das Pedras stream, the main watercourse of the park, only $150 \mathrm{~m}$ downstream from the sampling sites.

The climate in the region (southern part of the Espinhaço Range) is the Cwb type of the Köppen climate classification: mesothermal with hot rainy summers (from October to April) and cold dry winters (from June to August). The annual mean precipitation ranges from 1250 to $1550 \mathrm{~mm}$, and the mean temperature is approximately $18-19^{\circ} \mathrm{C}$, with a mean annual relative humidity of 75.6\% (NEves et al. 2005).

Sampling. Four sites were chosen for sampling in the Sentinela stream (Figure 1): site $1\left(18^{\circ} 11^{\prime} 09\right.$ " S- $43^{\circ} 36^{\prime} 55^{\prime}$ W; $1134 \mathrm{~m}$ above sea level - asl), site 2 ( $18^{\circ} 11^{\prime} \mathrm{O} 2$ " S- $43^{\circ} 37^{\prime} 04^{\prime \prime} \mathrm{W} ; 1125 \mathrm{~m}$ asl), site 3 ( $18^{\circ} 11^{\prime}$ o1" S-43 ${ }^{\circ} 37^{\prime} 06$ " W; $1106 \mathrm{~m}$ asl) and site 4 (18 $8^{\circ} 10^{\prime} 55^{\prime \prime}$ $\mathrm{S}-43^{\circ} 37^{\prime} 10^{\prime \prime} \mathrm{W} ; 1086 \mathrm{~m}$ asl). Site 1 had the best-preserved riparian vegetation of the four sites, with litter retention, slow flow, mud substrate, and no waterfalls. Site 2 had better-preserved riparian vegetation than sites 3 and 4, with litter retention, moderate flow, and sandy pebble sediment substrate. Sites 3 and 4 had poorly preserved riparian vegetation, no litter retention, and bottom substrate composed of sand and small loose stones with sediment. The first two sites have low-impact tourism (LIT) because they lack attractive features for the tourists (waterfalls, pools, etc.) and are also difficult to access (no trails, rock climbing). The other two sites are highly impacted by tourism (HIT) because they have much more attractive features and are easily accessed by a great number of visitors. The main physical and chemical features (velocity, conductivity, $\mathrm{pH}$, DO, temperature, width, depth and sediment) of the stream were measured during three months in the dry season (June, July and August) and the rainy season (November, December and January) using appropriate portable multi-parameter monitoring instruments.

Samples were collected monthly from January through December 2011, except in April, June and November, when the samples were taken before and after the holidays (after and before Carnival the samples were taken in February and March, respectively), totaling 15 samples (1: Jan 21, 2: Feb 21, 3: Mar 11, 4: Apr 12, 5: Apr 25, 6: May 27, 7: Jun 17, 8: Jun 28, 9: Jul 16, 10: Aug 19, 11: Sep 27, 12: Oct 25, 13: Nov 11, 14: Nov 22, 15: Dec 11). These four holidays (Carnival: Mar 6-9, Tiradentes: Apr 21-22, Corpus Christi: Jun 23-24, Republic Proclamation: Nov 14-15) were chosen because each one has, at least, three days attracting a great number of tourists (much higher than weekdays or weekends) to visit the park for recreation.

The aquatic insects were collected with an entomological net (Kick seine) with a 500- $\mu$ m mesh size. At each sampling site, three sampling units were taken by disturbing the substrate (stones, litter, sand) using the aquatic net (for details about the kick method, see BRUA et al. 2011) for $1 \mathrm{~min}$, allowing the insects to drift into the net. Following sorting and identification using a stereomicroscope, the organisms were preserved in $7 \%$ formalin and deposited in the reference collection of the Laboratory of Invertebrate Zoology/UFVJM.

The data for the number of tourists visiting the park were taken from a survey conducted by rangers of the Instituto Estadual de Floresta (IEF), from January 2009 through December 2011. The meteorological data (precipitation) were acquired from the meteorological station (INMET) located at Diamantina, Minas Gerais ( $18^{\circ} 15^{\prime}$ S- $43^{\circ} 36^{\prime}$ W; 1296 m asl).

Data Analysis. The Shannon-Weiner diversity and evenness (MAGURRAN 1991) of the sites were compared with t-tests. All the statistical analyses were performed in PAST 2.16 software (HAMmer et al. 2001, freely available at http://folk.uio.no/ ahammer/past).

An adaptation of the Biological Monitoring Work Party System (BMWP), modified by Alba-Tercedor \& SÁnchez-Órtega (1988) and Junqueira et al. (2000), and the Average Score Per Taxon (ASPT) were used to evaluate the biotic integrity of communities. The BMWP is a system for scoring the pollution tolerance for invertebrate (benthic macrofauna) families, where pollutionintolerant families receive high scores, whereas pollution-tolerant families are given low scores (СотА et al. 2002). The pollution-

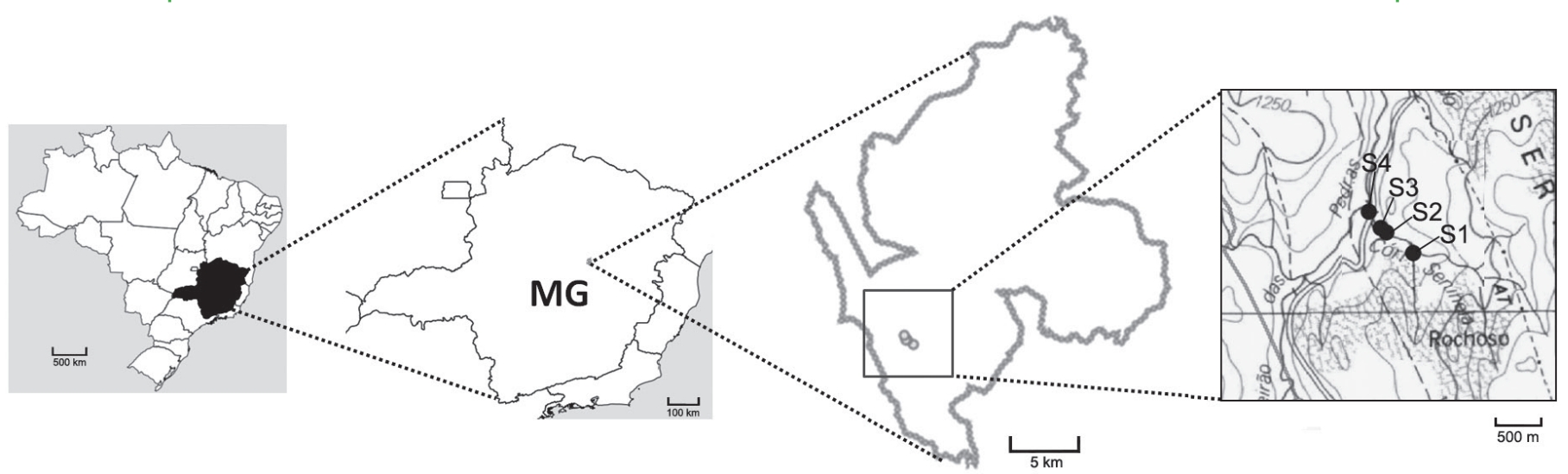

Figure 1. Location of the study area indicating the four collection sites (S1, S2, S3 and S4) in the protected area of Biribiri State Park, Diamantina, Minas Gerais. 
intolerant invertebrates families will receive scores close to 10 and the pollution-tolerant invertebrates families will receive scores close to 1.The ASPT index is the value of the Biological Monitoring Working Party index (BMWP) divided by the total number of families collected and provides a mean index of the families found in a stream (JACOBSEN et al. 2003).

The t-test was used to evaluate differences of physical variables between dry and rainy seasons, whereas the stream current differences of the sampling sites independent of the season were tested using the Kruskal-Wallis test followed by the post hoc Student-Newman-Keuls test $(\mathrm{p}<0.05)$.

The differences in insect abundance and richness before and after the holidays were evaluated using a $\mathrm{G}$ test $(\mathrm{p}<0.05)$. The differences in insect abundance and richness among the sites were tested using the Kruskal-Wallis test followed by the post hoc Student-Newman-Keuls test $(\mathrm{p}<0.05)$. The latter test was also used to check the differences in the BMWP and ASTP indexes among the sites. The Pearson correlation coefficient (r), with a significance level of 0.05, was used to evaluate the correlations between insect abundance and temperature or richness and temperature, as well as the number of tourists and insect abundance and richness. All three tests were performed with BioEstat 5.0 software (Ayres et al. 2007).

\section{RESULTS}

Environmental Variables. The stream was characterized by low depths, slightly acidic waters, high concentrations of dissolved oxygen, low values of specific conductivity and a current with strong seasonal differences. Independent of the season, site 1 showed the lowest stream current compared to the other sites (Table 1)

Grouping the data of the sites and evaluating the seasonal variation, $\mathrm{pH}$ and stream current showed significant differences between dry and rainy seasons in the four different sites. By contrast, water temperature showed significant differences in sites 1, 2 and 3, and dissolved oxygen showed significant differences in sites 1 and 2. The stream segments showed relatively similar aspects regarding conductivity, as no significant difference was observed between the two seasons (Table 1).

The parameters of stream current, conductivity and water temperature showed higher mean values in the rainy season, whereas dissolved oxygen and $\mathrm{pH}$ showed higher mean values in the dry season (Table 1 ).

Insect Abundance, Richness, and Stream Quality Indexes (BMWP and ASPT). 3601 individuals of aquatic insects were sampled, representing 8 orders and 41 families (Table 2). Despite this large number of families, $70 \%$ of the individuals collected belonged to only six families: Naucoridae, Notonectidae, Hydrophilidae, Gomphidae, Euthyplociidae and Baetidae.

Neither insect abundance $(\mathrm{r}=-0.364 ; \mathrm{p}=0.27)$ nor taxon richness $(\mathrm{r}=-0.235 ; \mathrm{p}=0.46)$ were significantly correlated with monthly precipitation, although both insects abundance and richness tended to increase in the dry season (Figure 2A-B).

Regarding the insect abundance and richness at site 1, 2427 individuals belonging to 21 families were collected; at site 2, 687 individuals belonging to 18 families; at site 3, 90 individuals belonging to 9 families; and at site 4, 405 individuals belonging to 10 families (Table 3). Naucoridae was the most abundant and frequent taxon found during the study period and also at all sites. Baetidae, Chironomidae, Coenagrionidae, Corixidae, Dytiscidae, Elmidae, Gomphidae, Leptoceridae, Naucoridae, Notonectidae, Odontoceridae and Tipulidae were also found in all sites, but at lower abundance (Table 3).

The Shannon-Wiener index for diversity did not differ significantly (t test, $\mathrm{p}>0.05$ ) among the four sites. The highest scores were found for sites 2 and $4\left(H^{\prime}=2.28\right.$ and $H^{\prime}=2.40$, respectively) and the lowest scores for sites 1 and $3\left(\mathrm{H}^{\prime}=1.95\right.$ and $\mathrm{H}^{\prime}=1.80$, respectively) (Table 3 ). Values of the equitability index showed the same pattern as the diversity index: lowest at site 1 and highest at site 4 (Table 3 ).

Most taxa occurred in very low numbers throughout the year (e.g., Belostomatidae, Pleidae, Gerridae, Nepidae, Veliidae, Hydropsychidae, Xiphocentronidae, Hydrobiosidae). Taxa present at the four sites consisted of a mixture of high- and lowBMWP scoring groups (e.g., Odontoceridae: 10, Chironomidae: 2). The BMWP indices obtained for the Sentinela stream indicated a marked difference between the LIT and HIT sites in the BMWP scores: sites 1 (218) and 2 (208) had excellent water quality, site 3 (87) had average water quality, and site 4 (127) had good water quality (Table 3). Comparisons of the BMWP values among sampling sites showed that site 1 was significantly different from site 3 (Kruskal-Wallis, p<0.0001) and site 4 (Kruskal-Wallis, $\mathrm{p}=0.006$ ), but not significantly different from site 2 (KruskalWallis, $\mathrm{p}=0.769$ ). The same tendency was observed in the ASPT scores, where the LIT sites had higher scores (site 1: 6.6; site 2: 6.7) than the HIT sites (site 3: 5.4; site 4: 5.5). However, these differences were not statistically significant (Kruskal-Wallis, $\mathrm{p}>0.05$ ).

Impact of Holidays and the Distribution Pattern of Aquatic Insects. Biribiri State Park received close to 130,000

Table 1 . General features (mean \pm standard deviation) of the Sentinela stream. The samples were collected during three months in the rainy and dry seasons.

\begin{tabular}{|c|c|c|c|c|c|c|c|c|}
\hline \multirow[b]{2}{*}{ Measurements } & \multicolumn{2}{|c|}{ Site 1} & \multicolumn{2}{|c|}{ Site 2} & \multicolumn{2}{|c|}{ Site 3} & \multicolumn{2}{|c|}{ Site 4} \\
\hline & $\begin{array}{c}\text { dry } \\
\text { season }\end{array}$ & $\begin{array}{c}\text { rainy } \\
\text { season }\end{array}$ & $\begin{array}{c}\text { dry } \\
\text { season }\end{array}$ & $\begin{array}{c}\text { rainy } \\
\text { season }\end{array}$ & $\begin{array}{c}\text { dry } \\
\text { season }\end{array}$ & $\begin{array}{c}\text { rainy } \\
\text { season }\end{array}$ & $\begin{array}{c}\text { dry } \\
\text { season }\end{array}$ & $\begin{array}{c}\text { rainy } \\
\text { season }\end{array}$ \\
\hline Stream current (m/s) & $\begin{array}{l}0.016 \pm \\
0.003 a\end{array}$ & $\begin{array}{c}0.037 \pm \\
0.011 b\end{array}$ & $\begin{array}{c}0.084 \pm \\
0.016 a\end{array}$ & $\begin{array}{c}0.298 \pm \\
0.173 b\end{array}$ & $\begin{array}{c}0.100 \pm \\
0.051 a\end{array}$ & $\begin{array}{c}0.187 \pm \\
0.07 \mathrm{~b}\end{array}$ & $\begin{array}{c}0.180 \pm \\
0.062 a\end{array}$ & $\begin{array}{l}0.379 \pm \\
0.202 b\end{array}$ \\
\hline Conductivity ( $\mu \mathrm{S} / \mathrm{cm})$ & $\begin{array}{c}0.003 \pm \\
0.001\end{array}$ & $\begin{array}{c}0.005 \pm \\
0.002\end{array}$ & $\begin{array}{c}0.003 \pm \\
0.001\end{array}$ & $\begin{array}{c}0.005 \pm \\
0.003\end{array}$ & $\begin{array}{c}0.002 \pm \\
0.001\end{array}$ & $\begin{array}{c}0.005 \pm \\
0.002\end{array}$ & $\begin{array}{c}0.005 \pm \\
0.002\end{array}$ & $\begin{array}{c}0.008 \pm \\
0.003\end{array}$ \\
\hline $\mathrm{pH}$ & $\begin{array}{l}5.62 \pm \\
0.03 a\end{array}$ & $\begin{array}{c}4.86 \pm \\
0.25 \mathrm{~b}\end{array}$ & $\begin{array}{c}5.80 \pm \\
0.05 a\end{array}$ & $\begin{array}{c}4.86 \pm \\
0.37 b\end{array}$ & $\begin{array}{c}6.02 \pm \\
0.16 \mathrm{a}\end{array}$ & $\begin{array}{c}4.97 \pm \\
0.45 b\end{array}$ & $\begin{array}{c}6.55 \pm \\
0.41 a\end{array}$ & $\begin{array}{c}5.33 \pm \\
0.71 b\end{array}$ \\
\hline Dissolved oxygen (mg/l) & $\begin{array}{l}8.67 \pm \\
0.38 a\end{array}$ & $\begin{array}{l}7.38 \pm \\
0.48 b\end{array}$ & $\begin{array}{l}8.21 \pm \\
0.52 a\end{array}$ & $\begin{array}{c}6.95 \pm \\
0.87 b\end{array}$ & $8.67 \pm 1.31$ & $7.25 \pm 0.35$ & $8.34 \pm 0.62$ & $7.97 \pm 0.73$ \\
\hline Water temperature $\left({ }^{\circ} \mathrm{C}\right)$ & $17.7 \pm 1.29 a$ & $\begin{array}{c}20.8 \pm \\
0.98 b\end{array}$ & $18.5 \pm 1.26 \mathrm{a}$ & $\begin{array}{l}21.2 \pm \\
1.04 b\end{array}$ & $17.8 \pm 1.76 a$ & $21.3 \pm 1.35 b$ & $19.0 \pm 3.11$ & $21.3 \pm 0.54$ \\
\hline Width (m) & & 5 & & 13 & & 14 & & 12 \\
\hline Predominant sediment & \multicolumn{2}{|c|}{ mud and pebbles } & \multicolumn{2}{|c|}{ pebbles } & \multicolumn{2}{|c|}{ pebbles and sand } & \multicolumn{2}{|c|}{ pebbles and sand } \\
\hline
\end{tabular}

* Different letters indicate significant differences at $\mathrm{p} \leq 0.05$ 
Does Tourism Impact Aquatic Insects in a High Altitude Stream?

Table 2. Aquatic insect abundance along the Sentinela stream during the rainy and dry seasons of 2011.

\begin{tabular}{|c|c|c|c|c|c|c|c|c|c|c|c|c|c|}
\hline Order & Family & jan & feb & mar & apr & may & jun & jul & aug & sep & out & nov & dez \\
\hline \multirow{3}{*}{ Diptera } & Chironomidae & & 12 & & 1 & 51 & 1 & 2 & 17 & 15 & & 2 & 2 \\
\hline & Tipulidae & 2 & 2 & & 3 & 2 & 1 & 2 & 6 & 1 & 2 & 1 & 3 \\
\hline & Simuliidae & & & & & & & & 1 & & & & 2 \\
\hline \multirow{9}{*}{ Hemiptera } & Mesoveliidae & & 1 & & & & & & & & & & \\
\hline & Naucoridae & 19 & 104 & 53 & 276 & 131 & 140 & 91 & 100 & 93 & 116 & 294 & 109 \\
\hline & Notonectidae & & 25 & 1 & 29 & 36 & 38 & 21 & 29 & 20 & 37 & 133 & 17 \\
\hline & Corixidae & & & & & & 12 & 58 & 5 & 1 & & 2 & 1 \\
\hline & Belostomatidae & & & & 2 & & 3 & & & & & 1 & \\
\hline & Pleidae & & & & & & 3 & 2 & 13 & 3 & 2 & & \\
\hline & Gerridae & & & & & & & & & & 1 & 1 & \\
\hline & Nepidae & & & & & & & & & & & 1 & \\
\hline & Veliidae & & & & & & & & & & & 2 & 1 \\
\hline \multirow{7}{*}{ Tricoptera } & Odontoceridae & & 5 & 3 & 6 & & 4 & 10 & 11 & 3 & 12 & 27 & 2 \\
\hline & Calamoceratidae & & & & & & & 1 & 2 & & & 1 & \\
\hline & Leptoceridae & & & & 27 & 10 & 7 & 3 & 2 & & & 5 & 42 \\
\hline & Hydroptilidae & & & & & & & & 10 & 12 & 1 & 1 & \\
\hline & Hydropsychidae & & & & & & & & & & & 1 & \\
\hline & Xiphocentronidae & & & & & & & & & & & 1 & \\
\hline & Hydrobiosidae & & & & & & & & & & & 2 & \\
\hline \multirow{7}{*}{ Odonata } & Aeshnidae & & 3 & & 6 & 6 & 2 & 2 & 2 & 1 & & 4 & \\
\hline & Libellulidae & 3 & 1 & & 5 & 6 & 21 & & & & & & \\
\hline & Gomphidae & 3 & 10 & 6 & 34 & 10 & 21 & 14 & 12 & 8 & 19 & 43 & 11 \\
\hline & Megapodagrionidae & & & & & 2 & & 6 & 8 & & 7 & 6 & 3 \\
\hline & Coenagrionidae & & 1 & & 3 & 8 & 11 & 3 & 13 & 10 & 7 & 11 & 6 \\
\hline & Corduliidae & & & & & & 1 & 4 & 8 & 6 & 11 & 29 & 2 \\
\hline & Perilestidae & & & & & & & & 3 & & 2 & 1 & \\
\hline \multirow{7}{*}{ Coleoptera } & Elmidae & 1 & 1 & & 12 & 16 & 41 & 1 & 3 & 1 & 1 & 2 & 3 \\
\hline & Dytiscidae & & & & & 5 & 10 & 16 & 5 & 12 & & 19 & 1 \\
\hline & Hydrophilidae & & & & 14 & & 11 & 90 & 39 & 120 & & 9 & \\
\hline & Chrysomelidae & & & & & & & & & & & & \\
\hline & Psephenidae & 3 & 3 & & & & & & & & & 1 & 1 \\
\hline & Limnichidae & & & & & & & & & & & 1 & \\
\hline & Gyrinidae & & & & & & & & & & & & 1 \\
\hline Megaloptera & Corydalidae & & 1 & & & & & & 1 & & & & \\
\hline \multirow{6}{*}{ Ephemeroptera } & Baetidae & & 1 & & 4 & 18 & 5 & 4 & 4 & 12 & 13 & 36 & 35 \\
\hline & Oligoneuriidae & & 1 & & & 6 & 20 & & & & & & \\
\hline & Leptohyphidae & & 1 & 2 & & & & 1 & 5 & & & & \\
\hline & Leptophlebiidae & & & & 1 & & & 4 & 2 & & 3 & 1 & 5 \\
\hline & Caenidae & & & & & & 2 & & 1 & & & & \\
\hline & Euthyplociidae & & & 1 & 17 & 13 & 28 & 31 & 28 & 7 & 18 & 18 & 7 \\
\hline Lepidoptera & Pyralidae & & & & & 3 & 2 & 1 & & & & & \\
\hline
\end{tabular}


Table 3. Aquatic insect abundance in each of the sampling sites during the rainy and dry seasons of 2011.

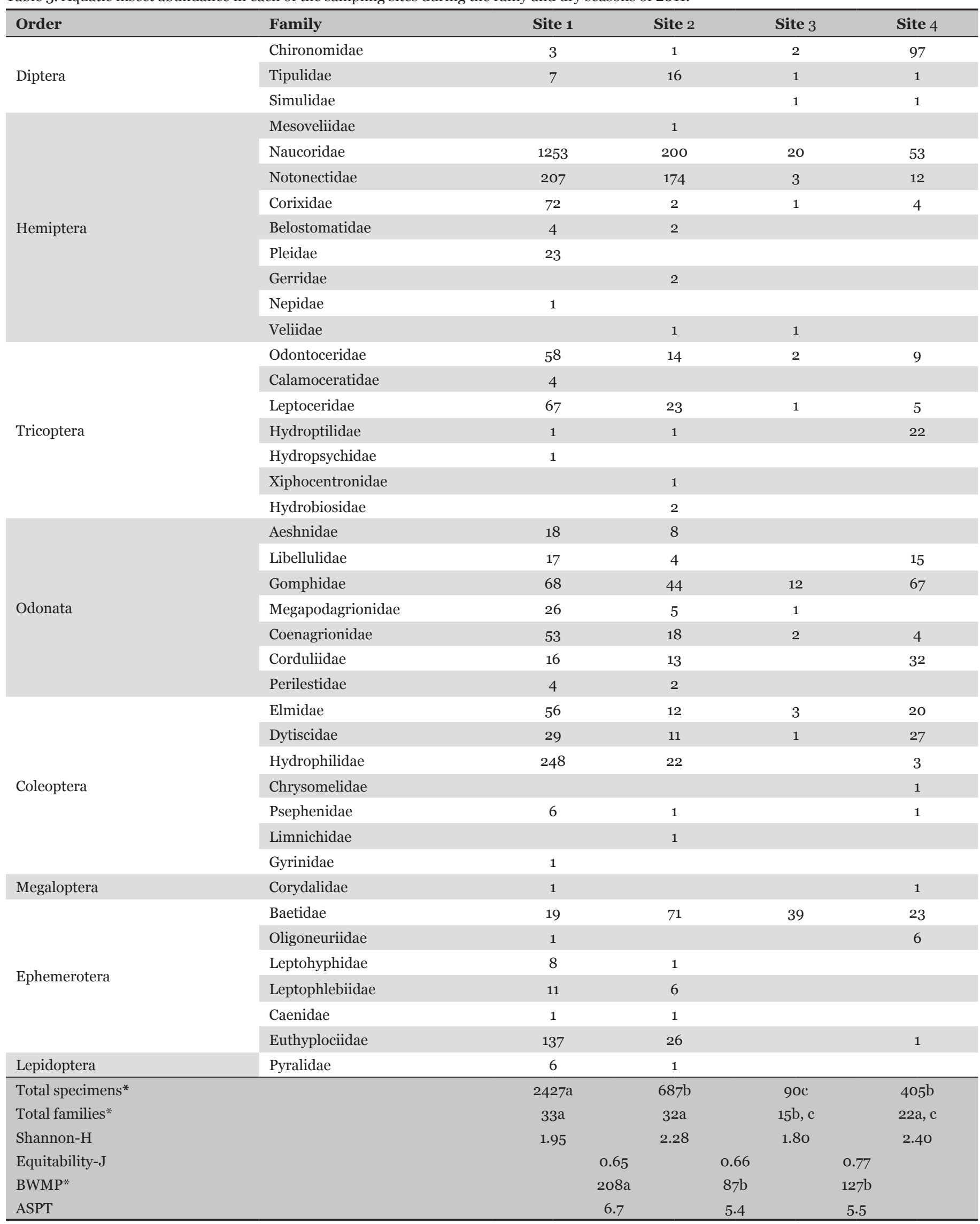

* Different letters indicate significant differences at $\mathrm{p} \leq 0.05$.

tourists from 2009-2011 (Figure 3). The highest number of tourists was observed in January, February, September and October (Figure 3). During 2011, the period of this study, the park received approximately 43,000 tourists, with 20,175 recorded from January to March (Figure 3).

Pearson's correlation analysis among the variables measured (richness, abundance and number of tourists) during 2011 showed that when the number of tourists in the park increased, the total insect abundance $(\mathrm{r}=-0.6382, \mathrm{p}=0.025)$ and richness decreased $(\mathrm{r}=-0.7816, \mathrm{p}=0.003)$, showing a negative impact of tourists on insect abundance and richness at the sampling sites.

Significant differences were also observed in insect abundance between the samples taken before and after the Carnival, Tiradentes and Corpus Christi holidays (Figure 4A). Although 


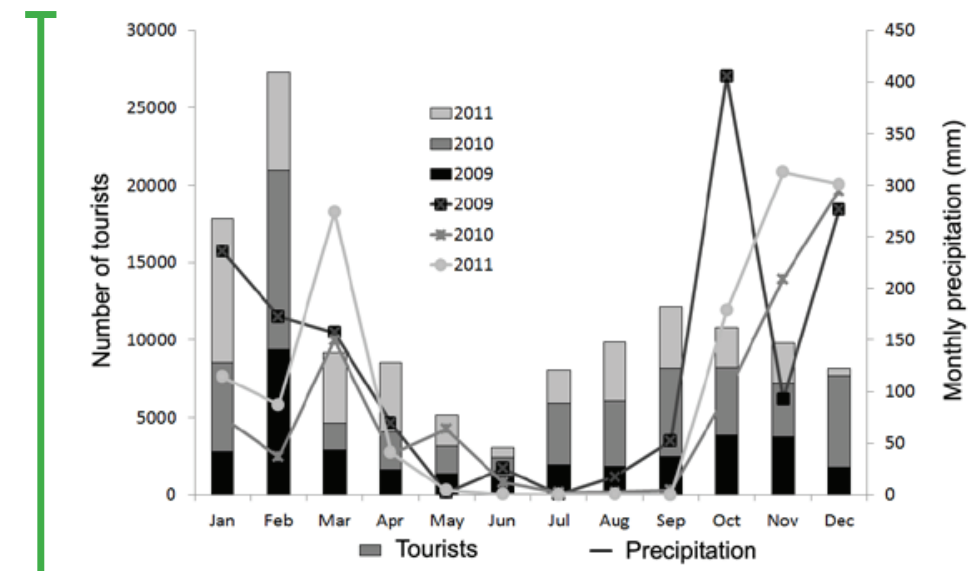

Figure 2. The relationship between precipitation and insect abundance (A) and insect richness (B), from Sentinela stream, Diamantina, Minas Gerais, during 2011.

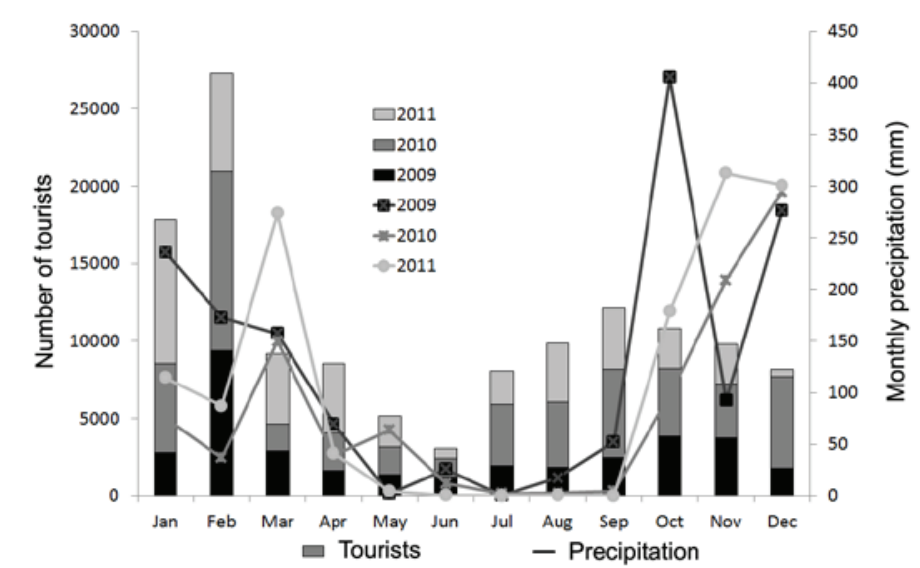

Figure 3. Number of tourists and monthly precipitation from 2009 to 2011 at Biribiri State park, Diamantina, Minas Gerais.

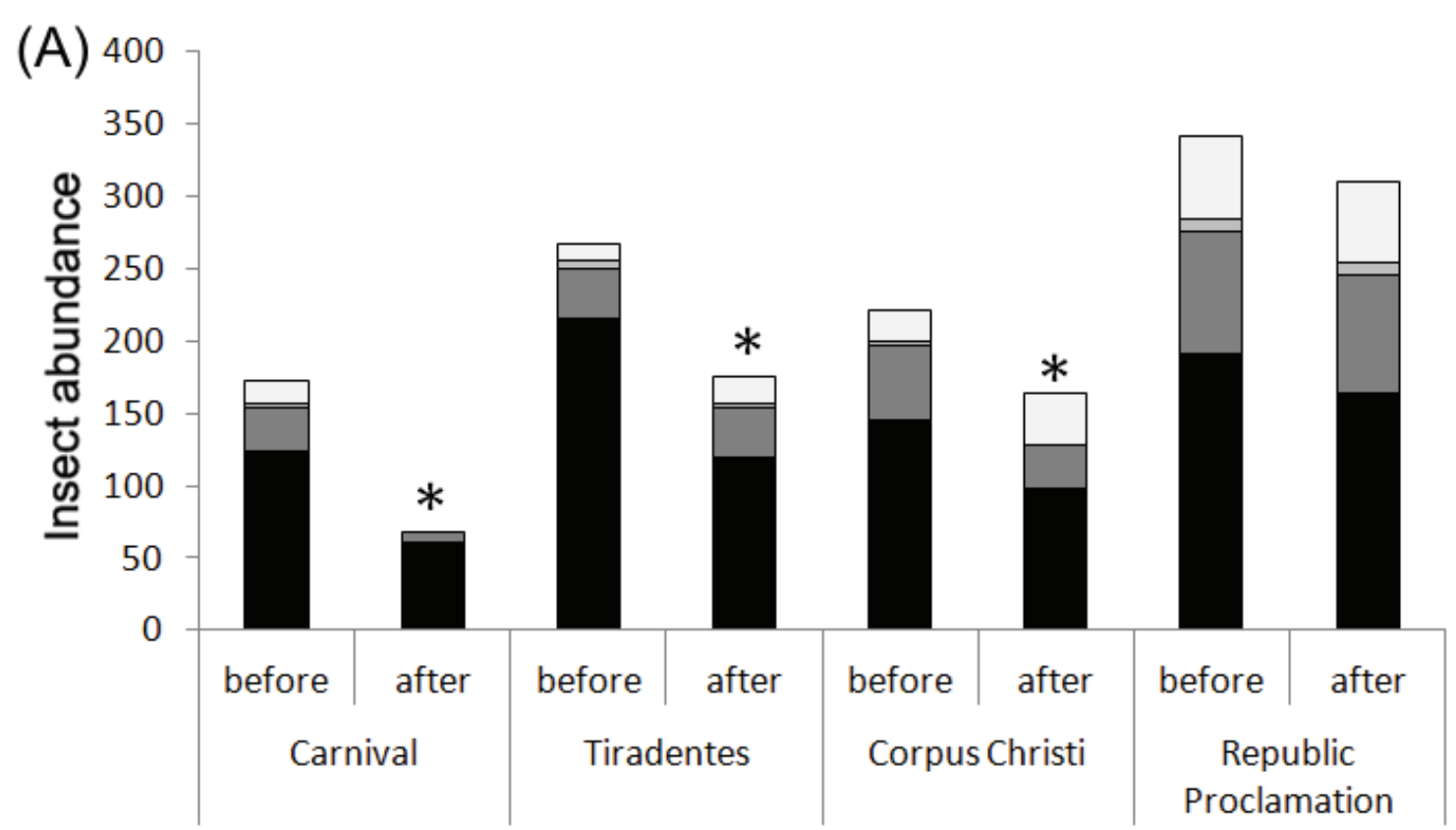

(B)

口 Site $1 \quad \square$ Site $2 \quad \square$ Site $3 \quad \square$ Site 4

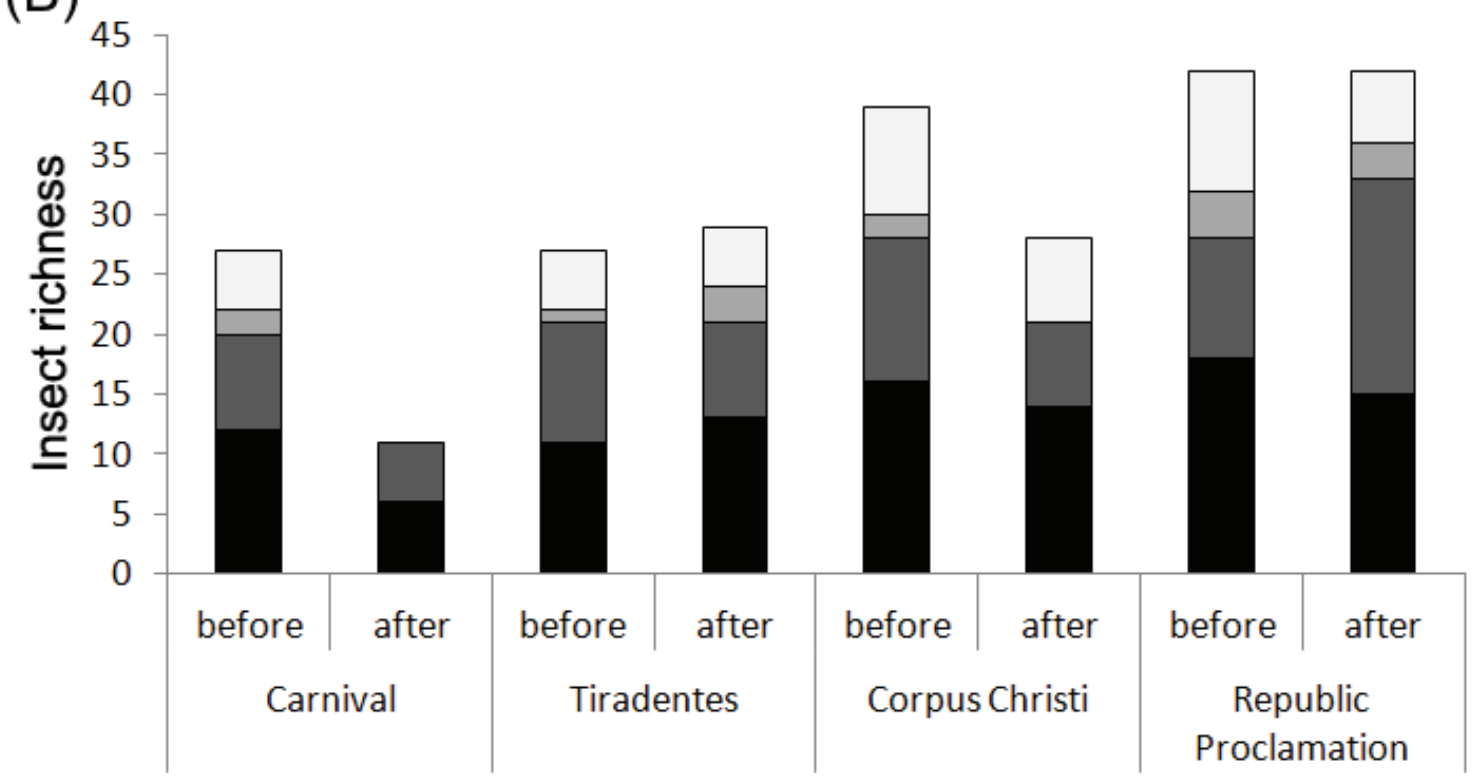

อ̆

a Site $1 \square$ Site $2 \quad \square$ Site $3 \quad \square$ Site 4

Figure 4. (A) Insect abundance and (B) insect richness before and after holidays (Carnival, Tiradentes, Corpus Christi and Republic Proclamation) in the four sites at Sentinela stream, Diamantina, Minas Gerais. * ${ }^{*}$ ignificant difference at $\mathrm{p} \leq 0.05$. 
the insect abundance after the Republic Proclamation holiday was also lower than before the holiday, this difference was not statistically significant. Insect richness did not significantly change after the holidays (Figure 4B). The decrease of insect abundance after holidays ranged from $23 \%$ at site 4 to $88 \%$ at site 3 , and the decrease of insect richness ranged from $20 \%$ at site 1 to $56 \%$ at site 3 . At site 3 , the decrease was greater than at the other sites.

\section{DISCUSSION}

The sediment in aquatic ecosystems consists of a wide variety of organic and inorganic materials from autochthonous and allochthonous inputs and play an important role in the structuring of stream ecosystems. The substrate affects the availability of habitats, feeding, and protection of the local biota (BISPO et al. 2006; Ligeiro et al. 2010). The accumulated organic debris increases the amount of food resources for benthic macroinvertebrates (КовAYASHI \& KagAYA 2002; Hoover et al. 2006), provides more space for colonization and refuge, and allows the establishment of fauna with larger individuals (DoBson 1991; RICHARDSON 1992).

Because the riparian zone is intimately associated with the stream, it is expected that sites 1 and 2, with dense vegetation cover, high accumulation of leaf debris, and mud bottoms (especially in site 1), will have higher abundance, richness, BWMP and ASPD scores. The families that were dominant at site 1 are less tolerant to pollution and more likely to be restricted to well-oxygenated waters (RESH \& JACKSON 1993; JoHNSON et al. 1993; WETZEL 2001). All families found at site 1 were also found at site 2 but in a lower abundance. At the other sampling sites, with little vegetation cover and sandy pebble sediment substrate, the opposite situation was observed, with lower abundance, richness, BWMP and ASPD scores (this was especially true for site 3). At site 4, the absence of several BMWP high-score groups (Plecoptera, Trichoptera) was compensated for by the increase in the number of aquatic insects of BMWP low-score families (e.g., Heteroptera, Coleoptera and Odonata), as also observed by RiERADEvall et al. (1999). Thus, the predominance of some families at sites 1 and 2 was an indicator of the better quality of this station compared with sites 3 and 4, which showed very low levels of individual abundance and richness. These results indicate that the accumulation of organic debris on the stream bottom seems to be a determining factor for supporting high population densities and species richness in the stream environment.

Although there is a strong relationship between macroinvertebrate richness and the substrate structure and composition (CALLISTO \& ESTEVES 1996), different degrees of tourist activity in a stream can also cause varying impacts on the aquatic fauna (BUCKLEY 2003). Tourism seems to increase the impact on stream ecosystems, as this effect is related to changes in species composition of the communities and a loss of community richness. The significant increase in tourists during the holidays may result in disturbance of the bottom sediment by trampling, foot traffic or swimming and consequent removal of the aquatic insects, thus reducing their local abundance (MEADOws 2001). The greater the degree of this interference is, the clearer the response of the aquatic insect community to disturbance at the sites because anthropogenic disturbances can modify patterns and processes in the natural environment (BARBOUR et al. 1999; CALLISTO et al. 2001, 2002; LigEIRo et al. 2013). In general, the trampling of the stream bottom and the water movement caused by tourists in the Sentinela stream resulted in the observed environmental changes. The low insect abundance and richness at sites 3 and 4 may indicate degradation at these sites along the middle course of the Sentinela stream, caused by uncontrolled tourism. As stated by JoHnson et al. (1993), low values for diversity can be interpreted as a result of environmental disturbance.

The diversity of taxa generally changes with decreases in ecosystem quality (RESH \& JACKSON 1993). Site 3 showed the lowest individual abundance and richness of all the sites. This site is the most fragile of the four sites because it has a small area and is easily accessible to tourists. Site 4 also had a high number of tourists, but showed larger numbers of chironomids. Members of Chironomidae are resistant organisms and are able to colonize environments with a low oxygen content (MARQUES et al. 1999). Moreover, these insects can be abundant in streams exposed to anthropogenic interference, which makes them effective indicators of environmental degradation (CAIRNS-JR \& PratT 1993; Marques et al. 1999).

The negative effect of the mechanical action of people on the structures of the sediment and the benthic community was demonstrated in a study conducted on a stretch of the Formoso River by MEDINA-JR (2007). Using an experimental approach, the author found that the water movement and trampling on the bottom caused the resuspension and movement of sediments and leaf detritus. Because they are soft substrates, these materials are more susceptible to mechanical disaggregation and are transported downstream by the current, reducing debris accumulation and consequently decreasing the amount of food resources available for benthic macroinvertebrates. Furthermore, although it is known that aquatic insects drift continuously in a stream, this mechanical disaggregation can also increase the number of drifting animals to levels much higher than in untrampled areas (BRITTAIN \& EIKELAND 1988).

Unlike studies in temperate regions, studies of invertebrate drift are not common in tropical lotic systems (FleCKER\& FeIfareK 1994; CALlisto \& Goulart 2005). The turbulent flow caused by heavy precipitation during the rainy period could result in a sparse and low-diversity insect fauna, suggesting that the physical disturbance of the substrate dislodges the benthic fauna causing temporal instability in the assemblage composition (Poff \& Ward 1991; Flecker \& FeIfareK 1994). Some authors (e.g. Flecker \& FeIfarek 1994) have found that a heavy rainstorm, defined as precipitation higher than $25 \mathrm{~mm}$, may cause pronounced declines in the insect community.

Most of the studies conducted in tropical regions (FLECKER \& FeifareK 1994; Bispo \& Oliveira 1998; Callisto \& Goulart 2003; Bispo et al. 2006) reported differences in the taxonomic richness and diversity of the drifting invertebrate community during the rainy and dry periods, indicating a significant influence of seasonality. This situation is very clear in the Brazilian Cerrado, where the perturbations are more intense and frequent during the November to April period of heavy precipitation (BIsPo et al. 2006). However, the data obtained in the present study did not indicate an influence of precipitation on the aquatic insect fauna. The community fauna analyzed in the Sentinela stream did not undergo seasonal alterations despite differences in flow (the total amount of precipitation over the period varied from null to 312 $\mathrm{mm}$ in July and November, respectively).

The absence of a correlation between precipitation and the aquatic insect fauna in the Sentinela stream can be interpreted in two ways: a) as an adaptation of the insect fauna to the different equilibrium states during the year, at least in years without unusual catastrophic floods (Melo \& Froehlich 2001); or b) the insect fauna recovered rapidly, even with the physical disturbance caused by higher flow during precipitation (HARDIMAN \& BURGIN 2011).

However, another interpretation of the absence of this correlation is possible, in view of one of the conclusions by Ligeiro et al. (2013). Their study demonstrated that when the anthropogenic impact is not strong, the changes in the faunal structure in the stream will be associated with natural variability. As sites 3 and 4 showed high anthropogenic impact due to the effect of the intense disturbance caused by the large numbers of tourists, the absence of a significant difference could be related to 
the incapacity of our data to detect habitat variation, even when compared to the less-impacted sites 1 and 2.

In conclusion, in addition to natural changes, the different ecosystems are subject to anthropogenic impacts. Among these impacts, uncontrolled tourism in parks can cause the environmental modification of water bodies due to the mechanical action of human activities. The responses of aquatic insects to the impacts of tourists may result from the direct effect of either trampling or modification of the bottom substrate which lead to a decreased diversity and abundance, as observed in the Sentinela stream.

\section{ACKNOWLEDGMENTS}

We thank Fabrício Coimbra for assistance during field sampling. We also thank Dr. Marcos Callisto for confirming the aquatic insect family identifications and the field employees of PEBI for all types of facilities and data about tourists. We thank Dr. Cristiano Christofaro for lending the multi-parameter monitoring instruments and also to anonymous referee for useful and constructive comments. Financial support was granted by Fundação de Amparo a Pesquisa de Minas Gerais (FAPEMIG). Climatology data were provided by Instituto Nacional de Meteorologia (INMET), $5^{\circ}$ Distrito de Meteorologia ( $5^{\circ}$ DISME).

\section{REFERENCES}

Alba-Tercedor, J. \& A. Sánchez-Órtega, 1988. Un método rápido y simples para evaluar la calidad biológica de las aguas corrientes basado en el de Hellawell (1978). Limnetica, 4: 5156.

Ayres, M., J.R.M. Ayres, D.L. Ayres, A.S. Santos, 2007. BioEstat 5.0-Aplicações Estatísticas nas Áreas das Ciências Biológicas e Médicas: Sociedade Civil Mamirauá, Belém. CNPq, Brasília, $290 \mathrm{p}$.

Barbour, M.T., J. Gerritsen, B.D. Snyder, J.B. Stribling, 1999. Rapid Bioassessment Protocols for Use in Streams and Wadeable Rivers: Periphyton, Benthic Macroinvertebrates and Fish (Second Edition). EPA/841-B-99-002. U.S. EPA, Office of Water, $197 \mathrm{p}$.

Bispo, P.C. \& L.G. Oliveira,1998. Distribuição espacial de insetos aquáticos (Ephemeroptera, Plecoptera e Trichoptera) em córregos de cerrado do Parque Ecológico de Goiânia, Estado de Goiás, pp. 175-189. In: Nessimian, J.L. and A.L. Carvalho (Eds.). Ecologia de Insetos Aquáticos, Rio de Janeiro, Oecologia Brasiliensis, 309 p.

Bispo, P.C., L.G. Oliveira, L.M. Bini \& K.G. Sousa, 2006. Ephemeroptera, Plecoptera and Trichoptera assemblages from riffles in mountain streams of central Brazil: environmental factors influencing the distribution and abundance of immatures. Brazilian Journal of Biology, 66: 611-622.

Brittain, J.E. \& T.J. Eikeland, 1988. Invertebrate drift - A review. Hydrobiologia, 166: 77-93.

Brua, R.M., J.M. Culp \& G.A. Benoy, 2011. Comparison of benthic macroinvertebrate communities by two methods: Kick- and U-net sampling. Hydrobiologia, 658: 293-302.

Buckley, R., 2003. Ecological indicators of tourism impacts in Parks. Journal of Tourism, 2: 54-66.

Cairns-Jr, J. \& J.R. Pratt, 1993. A history of biological monitoringusing benthic macroinvertebrates, p. 10-27. In: Rosenberg, D.M. and V.H.. Resh (Eds.). Freshwater Biomonitoring and Benthic Macroinvertebrates. New York, Chapman and Hall, 488 p.

Callisto, M. \& F.A. Esteves, 1996. Composição granulométrica do sedimento de um lago Amazônico impactado por rejeito de bauxita e um lago natural (Pará, Brasil). Acta Limnologica Brasiliensia, 8: 115-126.

Callisto, M. \& M.D.C. Goulart, 2005. Invertebrate drift along a longitudinal gradient in a Neotropical stream in Serra do Cipó National Park, Brazil. Hydrobiologia, 539:47-56.

Callisto, M., W.R. Ferreira, P. Moreno, M. Goulart, M. Petrucio,
2002. Aplicação de um protocolo de avaliação rápida diversidade de habitats em atividades de ensino e pesquisa (MG - RJ). Acta Limnologica Brasiliensia, 14: 91-98.

Callisto, M, M.D.C. Moretti \& M. Goulart, 2001. Macroinvertebrados bentônicos como ferramenta para avaliar a saúde dos riachos. Revista Brasileira de Recursos Hídricos, 6: 71-82.

Choai, H.C. \& E. Sirakaya, 2006. Sustainability indicators for managing community tourism. Tourism Management, 27: 1274-1289.

Cota, L.R., M.D.C. Goulart, P. Moreno \& M. Callisto, 2002. Rapid assessment of river water quality using an adapted BMWP index: a pratical tool to evaluate ecosystem health. Verhandlungen des Internationalen Verein Limnologie, 28: $1713-1716$.

Dinakaran, S. \& S Anbalagan. 2007.Anthropogenic impacts on aquatic insects in six streams of south Western Ghats. Journal of Insect Science, 7: 1-6.

Dobson, M., 1991. An assessment of mesh bags and plastic leaf traps as tools for studying macroinvertebrate assemblages in natural leaf packs. Hydrobiologia, 222: 19-28.

Flecker, A.S. \& B. Feifarek, 1994. Disturbance and temporal variability of invertebrate assemblages in two Andean streams. Freshwater Biology, 31: 131-142.

Goulart, M.D.C. \& M. Callisto, 2003. Bioindicadores de qualidade de água como ferramenta em estudos de impacto ambiental. Revista Digital FAPAM, 2: 78-85.

Hammer, Ø.; D.A.T. Harper \& P.D. Ryan, 2001. PAST: Paleontological Statistics Software Package for Education and Data Analysis. Palaeontologia electronica, 4: 1-9.

Hardiman, N. \& S. Burgin, 2011. Effects of trampling on in-stream macroinvertebrate communities from canyoning activity in the Greater Blue Mountains World Heritage Area. Wetlands Ecology and Management, 19: 61-71.

Hoover, T.M., J.S. Richardson \& N. Yoxemitsi, 2006. Flowsubstrate interactions create and mediate leaf litter resource patches in streams. Freshwater Biology, 51: 435-447.

Jacobsen, D., S. Rostgaard \& J.J. Vásconez, 2003. Are macroinvertebrates in high altitude streams affected by oxygen deficiency? Freshwater Biology, 48: 2025-2032.

Johnson, R.K., T. Wiederholm \& D. Rosenberg, 1993. Freshwater biomonitoring using individual organisms, populations, and species assemblages of benthic macroinvertebrates, p. 40158. In Rosenberg, D.M. and Resh, V.H. (Eds.) Freshwater biomonitoring and benthic macroinvertebrates. New York, Chapman and Hall, 488 p.

Junqueira, V.M., M.C. Amarante, C.F.S. Dias \& E.S. Franca, 2000. Biomonitoramento da qualidade das aguas da Bacia do Alto Rio das Velhas (MG/Brasil) através de macroinvertebrados. Acta Limnologica Brasiliensia, 12: 73-87.

Kerans, B.L. \& J.R. Karr, 1994. A benthic index of biotic integrity (B-IBI) for rivers of the Tennessee Valley. Ecological Applications, 4: 768-785.

Kobayashi, S. \& T. Kagaya, 2002. Differences in litter characteristics and macroinvertebrate assemblages between litter patches and riffles in a head water stream. Limnology, 3: 37-42.

Ligeiro, R., M.S. Moretti, J.F. Gonçalves-Jr \& M. Callisto, 2010. What is more important for invertebrate colonization in a stream with low-quality litter inputs: exposure time or leaf species? Hydrobiologia, 654: 125-136.

Ligeiro, R.M. Robert, R.M. Hughes, P.R. Kaufmann, D.R. Macedo, K.R. Firmiano, W.R Ferreira, D. Oliveira, A.S. Melo \& M. Callisto, 2013. Defining quantitative stream disturbance gradients and the additive role of habitat variation to explain macroinvertebrate taxa richness. Ecological Indicators, 25: 45-57.

Magurran, A.E., 1991. Ecological diversity and its measurement, London, Chapman and Hall, 178 p.

Marques, M.G.S.M., R.L. Ferreira \& F.A.R. Barbosa, 1999. A comunidadedemacroinvertebrados aquáticosecaracterísticas 
limnológicas das lagoas carioca e da barra, Parque Estadual do Rio Doce, MG. Revista Brasileira de Biologia, 59: 203210.

McGeoch, M.A., 2007. Insects and bioindication: theory and progress, p. 144-174. In: Stewart AJA, New TR, Lewis OT (Eds.) Insect conservation biology, Wallingford, CABI, $457 \mathrm{p}$.

Meadows, D.W., 2001. Effects of Bison trampling on stream macroinvertebrate community structure on Antelope Island, Utah. Journal of Freshwater Ecology, 16: 83-92.

Medina-Jr, P.B., 2007. Avaliação dos impactos da visitação pública no rio Formoso, Bonito, MS, Brasil: subsídeos à gestão ambiental do turismo em áreas naturais. Thesis, University of São Paulo, 156 p.

Melo, A.S. \& C.G. Froehlich, 2001. Macroinvertebrates in neotropical streams: richness patterns along a catchment and assemblage structure between 2 seasons. Journal of the North American Benthological Society, 20: 1-16.

Monz, C.A., C.M. Pickering \& W.L. Hadwen, 2013. Recent advances in recreation ecology and the implications of different relationships between recreation use and ecological impacts. Frontiers in Ecology and the Environment, 11: 441446.

Neves, S.C., P.A. Abreu \& L.M.S. Fraga, 2005. Fisiografia, p. 137-147. In: Silva, A.C., Pedreira, L.C.V.S.F. \& Abreu, A.O. (Eds.). Serra do Espinhaço Meridional: Paisagem e ambiente, O Lutador, Belo Horizonte, 272p.

Poff, N.L. \& J.V. Ward, 1991. Drift responses of benthic invertebrates to experimental stream flow variation in a hydrologically stable stream. Canadian Journal of Fisheries and Aquatic Sciences, 48: 1926-1936.

Resh, V.H. \& J.K. Jackson, 1993. Rapid assessment approaches to biomonitoring using benthic macroinvertebrates, p. 195233. In: Rosenberg, D.M. and Resh, V.H. (Eds.). Freshwater biomonitoring and bentic macroinverbrates. New York, Chapman and Hall, $488 \mathrm{p}$.

Richardson, N.J.S., 1992. Food, microhabitat, or both? Macroinvertebrate use of leaf accumulations in a montane stream. Freshwater Biology, 27: 169-176.

Rieradevall, M., M. Bonada \& N. Prat, 1999. Community structure and water quality in the Mediterranean streams of a natural N Park (St. Llorenço del Munt, NE Spain). Limnetica, 17: 4556.

Rodrigues, A.S.L., G. Malafaia \& P.T.A. Castro, 2008. Protocolos de avaliação de rios e a inserção da sociedade no monitoramento dos recursos hídricos. Ambiente \& Água - An Interdisciplinary Journal of Applied Science, 3: 143-155.

Tupinambás, T.H., R.M.V. Cortes, S.G. Varandas, S.J. Hughes, J.S. França \& M. Callisto, 2014. Taxonomy, metrics or traits? Assessing macroinvertebrate community responses to daily flow peaking in a highly regulated Brazilian river system. Ecohydrology, 7: 828-842.

Wetzel, R.G., 2001. Limnology: lake and river ecosystems, New York, Academic Press, 1006 p.

\section{Received in: 10/20/2014}

Accepted in: 03/05/2015

\section{Suggested citation:}

Bispo, C.A., A.P. Lourenço \& A.R.S. Garraffoni, 2015. Does Tourism Impact Aquatic Insects in a High Altitude Stream? EntomoBrasilis, 8 (2): 96104.

Available in: doi:10.12741/ebrasilis.v8i2.485
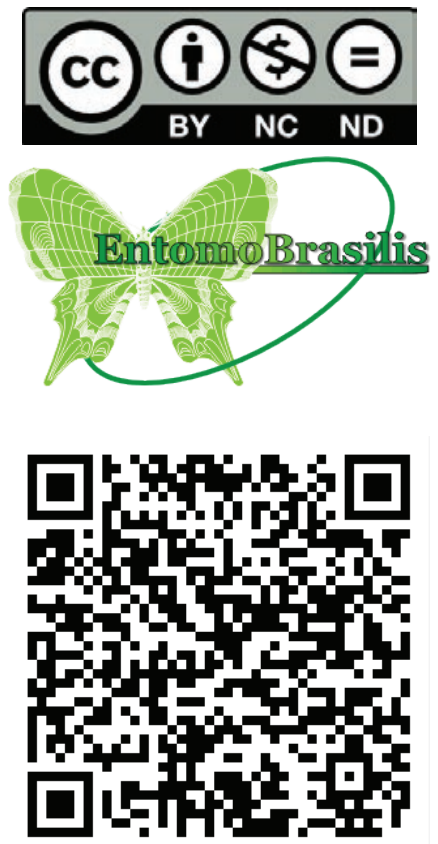